\title{
COMMENT
}

\section{ROAD RULES FOR OUR COUNTRY - AUSTRALIA'S CONSTITUTION AND AUSTRALIA'S FIRST PEOPLES}

\section{Senator Patrick Dodson and Graham Perrett MP}

There was a time when most Australian drivers would encounter a particular kind of defaced road sign in their travels. Speeding along the National Highway near the Broome turn-off in Western Australia or dodging kangaroos on the back roads of western Queensland around St George, drivers could see a sign urging them to 'FORM ONE LANE' transmogrified by some local wit to read 'FORM ONE PLANET'. Graffiti on signs in a vain attempt to make them say something else can be mildly amusing but completely ineffective. However, whilst it is dangerous (and illegal) to interfere with road signs, sometimes tinkering with an original symbol can achieve something worthwhile, and substantial.

There were no bitumen roads before colonisation. Roads are a symbol of colonisation in Australia. A sign of development, they divided up the country into a grid of states and territories with artificial boundaries. They were designed so the colonisers could traverse large distances at a fast pace. They are a sign of western modernity - of moving forward. The colonisers built the roads and they also wrote the 'road rules' for the nation, the Constitution.

The analogy of road rules is useful when thinking about the Australian Constitution. Most of the road rules for our nation are found in our Constitution. This foundation document 'constituted' the Commonwealth of Australia on the first of January 1901 and divides power between states and the central government - now often referred to metonym-like as 'Canberra'.

For countless generations before the current Constitution was imagined, the continent of Australia was subject to a complex and very different set of interlocking rules. Each area of Australia was home to a distinct Indigenous land holding group, who knew their territory in detail, and with a deep and ongoing connection. Distinct groups were also interconnected through song-lines, stories and rituals that drew connections across the lands of First Nations.

In Yawuru country around Broome, which Senator Dodson calls home, this knowledge and connection has evolved over vast amounts of time into a shared understanding that connects people to place, and people to each other. 
The Yawuru rules, shared and understood amongst the Yawuru people and respected by their neighbours such as the Nyikina, existed before time began, and were shaped in the Bugarigarra, what Westerner's romantically refer to as 'The Dreaming'. The Bugarigarra is the time before time, but which still exists today. Community, country and law is grounded in the Bugarigarra, the oldest continuing and ongoing legal tradition known to humanity.

But colonisation proceeded in Australia without acknowledgement of this ancient and ongoing legal heritage. The colonising forces failed to see at all that there were rules of law that determined land ownership, connection and use. Instead, the insidious myth of terra nullius (land belonging to no one) allowed the colonisers to ignore the rules of the land, ignore the interconnectedness of First Nations people, and proceed as if it was a case of vacant possession.

The colonies were established without consultation, without consent and without compensation. New rules were forced into place over the top of the ancient rules, which remained but were ignored.

The challenge for First Nations People is to maintain their laws, communities, customs and ongoing connection to land within a framework of colonisation that has never rightfully acknowledged their place as the First Peoples of this country, and never consulted them in the creation of the Constitution.

When the six former British colonies came together (without any Indigenous advice of course) they retained most of their law-making rights (as the states) but agreed to give the new Commonwealth the power to make laws about some specific topics. This list of so-called 'heads of power' that was a piece of legislation passed by Westminster can now be found in section 51 of our nation's (the Australian) Constitution. If there is an inconsistency between state laws and Canberra, section 109 of the Constitution provides that the Commonwealth law will prevail.

Most of the Australian nation's constitutional road rules are not well known. Occasionally a section does attract some publicity - such as section 44 , which forced an unforeseen number of members and senators to be expelled from the Federal Parliament over dual citizenship, ${ }^{1}$ but mostly the Constitution is only a matter of abiding interest for academics, legal students and concerned constitutional lawyers. Discussions around the Constitution are not exactly seen as scintillating yarns, but sections of the Constitution underpin our social institutions and social change. The powers of the Constitution hold real power and should never be dismissed as merely symbolic.

Section 71 of our nation's road rules created the High Court. Over the years, this court has gradually raised awareness of the road rules and clarified their

${ }^{1}$ See Bloch and Rubenstein pp. 79-101. 
meaning and interpretation. For example, in 1982 the High Court heard a challenge by the Queensland State Government of the Commonwealth's power to enact legislation under the external affairs power contained in section 51(xxix) of the Constitution. Koowarta v Bjelke-Petersen ${ }^{2}$ challenged the validity of the Racial Discrimination Act 1975 (Cth). The Commonwealth claimed the power to enact the Racial Discrimination Act 1975 (Cth) under the foreign affairs power, as it was legislated to give effect to Australia's obligations under the International Convention on the Elimination of All Forms of Racial Discrimination.

In Koowarta ${ }^{3}$ the Queensland Government had stopped the Aboriginal Land Fund Commission from acquiring the lease of grazing property for the use of $\mathrm{Mr}$ Koowarta and other members of a group of Aboriginal people in the Wik Lands near Aurukun in Cape York, Queensland.

Mr Koowarta had been acting in keeping with the laws and rules of his Wik peoples to gain a foothold on his ancestral lands. Those lands had been taken from him by the issuance of a pastoral lease over them. Mr Koowarta and his countrymen sought to gain access to the land by purchasing the lease of the Archer River property from an American businessman who held the lease.

The Queensland Minister of Lands in his reasons for the refusal to grant the lease said:

The Queensland Government does not view favourably proposals to acquire large areas of additional freehold or leasehold land for development by Aborigines or Aboriginal groups in isolation.

Understandably, Mr Koowarta believed that such a refusal was in breach of the Racial Discrimination Act 1975 (Cth) and challenged the decision. The Queensland State Government contended that the Racial Discrimination Act 1975 (Cth) was outside the external affairs power of the Commonwealth Parliament and was invalid.

It was only by a very small margin of four to three that the High Court held the Racial Discrimination Act 1975 (Cth) was valid and the Commonwealth did have power to overrule state laws through using the external affairs power in the Constitution.

Belatedly then, the High Court found that the Commonwealth did have the right to make laws for the people of any race; it did have the power to overturn racially discriminatory actions by a state government; it could enforce international conventions against racism to which the Australian nation-state had committed.

2 Koowarta v Bjelke-Petersen [1982] HCA 27, 153 CLR 168, 39 ALR 417.

3 Ibid. 
However, the decision did not recognise Mr Koowarta's rights to his ancestral lands.

The rules of the road remained the same.

Just one year after the decision in Koowarta,${ }^{4}$ the High Court once again heard a challenge to the Commonwealth's foreign affairs power in the Tasmanian Dams Case. ${ }^{5}$ The Tasmanian Government wanted to construct a hydro-electric dam on the Gordon River, on land that had previously been recognised as national park by the Tasmanian Government. However, it was later excised from the national park by specific Tasmanian legislation.

The Commonwealth reacted by enacting regulations in March 1983 to list the land as a World Heritage Conservation Area. The World Heritage (Western Tasmanian Wilderness) Regulations (Cth) prohibited, without ministerial consent, the construction of a dam or associated works on the land. The Tasmanian Government claimed that the Commonwealth legislation was beyond its powers and therefore invalid. The High Court held by a majority of four to three that the Commonwealth had validly used the external affairs power to enact legislation in order to carry out Australia's obligations under the Convention Concerning the Protection of the World Cultural and Natural Heritage.

Despite the narrow margin, the decision in the Tasmanian Dams Case ${ }^{6}$ was significant for affirming the extent of the Commonwealth power to make laws under the Australian Constitution. It recognised that the Commonwealth could draw down from its international treaty-making powers to override the laws of a state that were inconsistent with that international commitment. It was particularly significant in respect to the Commonwealth's power to make laws in relation to our environment.

Both Koowarta ${ }^{7}$ and the Tasmanian Dams Case $^{8}$ involved a prickly exchange of powers between a state and the Commonwealth. Although 'Canberra Bashing' is almost a national pastime, the former British colonies do also occasionally voluntarily refer some of their pre-1901 powers to the Commonwealth. In some cases, such as the Environment Protection and Biodiversity Conservation Act 1999 (Cth), there is a national agreement to define those matters that are of national significance, in which Canberra will have the overriding say.

However, as the states and territories have retained their power to legislate most environmental laws, it has resulted in our country having a de-centralised

\footnotetext{
${ }^{4}$ Ibid.

5 Commonwealth v Tasmania [1983] HCA 21, 158 CLR 1.

6 Ibid.

7 Koowarta (n 1).

8 Commonwealth v Tasmania (n 4).
} 
system and the Commonwealth Government role being significantly limited to those specific issues of national significance only.

On a limited number of occasions, Commonwealth power to legislate under the Constitution has also been modified through referendums, where the Parliament takes a question to the Australian voters and more than half of them support the question. Such proposals must also be carried in at least four of the six states. ${ }^{9}$

Since 1906 Australia has held 44 nation-wide referendums, spread out over nineteen different occasions. ${ }^{10}$ But it is hard to change our road rules this way: the public has only ever said 'yes' to eight proposals for constitutional change. Although the words of our Constitution were actually passed in a Parliament in another country by men who didn't belong here, the words were mostly crafted by blokes who actually did call Australia home. Unfortunately our nation's birth certificate made no mention of First Nations Peoples and the fact they had already been here for more than 60,000 years. They were not included in the drafting sessions, nor recognised in its substance.

Section 127 was titled 'Aborigines not to be counted in reckoning population' but this was amended by a 1967 public vote. ${ }^{11}$ In that significant referendum nearly 91 per cent of the voting public supported the amendment. This was a proposal with a strong moral case, no opposing campaign and clear support from both major parties in the Federal Parliament. These preconditions are necessary for the high bar of constitutional change to be safely hurdled.

In recent months, in Canberra, the Parliament has established a Committee to wrestle once again with the question of Indigenous Recognition in the Constitution. At the time of writing, this Committee, which Senator Dodson co-chairs, is holding hearings across the Kimberley and in Canberra. At every hearing First Nations People have puzzled over the fact that the Constitution does not in any way acknowledge their prior and ongoing ownership of the land and connection to country. Some simple truths are a long time in the knowing.

However, our nation's Road Rules did gain another Indigenous shift in 1992 through the agency of Chief Justice Mason's courageous High Court.

Mabo v Queensland (No 2) ${ }^{12}$ recognised native title in Australia for the first time. Even though David Passi, James Rice and Eddie Mabo were Meriam people from the Torres Strait the law changed for all Australia. And that was said by some to be the end of the world as we knew it. Terra nullius was found to be a lie.

\footnotetext{
9 See Scutt, 121-75.

10 Ibid.

11 Ibid.

12 Mabo v Queensland (No 2) [1992] HCA 23, 175 CLR 1.
} 
For the First Nations who owned and managed this continent for millennia, their spiritual and cultural beliefs were accepted as real by the highest court in the land. The High Court found in Mabo ${ }^{13}$ that the legal doctrine of terra nullius which imported all of England's road rules down-under did not apply equally everywhere. The fact that people had been travelling their own song-lines for around 60,000 years suddenly mattered. Existing customary laws and traditional connections to land trumped the English notion of terra nullius. The ancient past prevailed despite many acts done on behalf of the sovereign and often irrespective of white people arriving in an area. Some native title rights could be extinguished by governments but this process was not as automatic as previously assumed when the concept of terra nullius was thought to be impregnable and beyond question.

After Mabo ${ }_{14}^{14}$ the Commonwealth Parliament passed Native Title legislation in a lengthy and hostile Parliamentary session.

Thereafter, once Traditional Owners demonstrated a connection to their land they could then be involved in decisions about how best to protect it.

The legislative change was one of Prime Minister Keating's (1991-96) practical building blocks of change and social justice.

Since the Second World War Australia has accepted around seven million immigrants. They and their children and grandchildren now belong. They are also connected to a land that holds the oldest footprints in the world.

But we consider that there may be a simple bureaucratic procedure to make all non-Indigenous Australians even better belong.

When the High Court created the $M a b o^{15}$ wave it was Keating who metaphorically handed out surfboards, trying to take Australians all the way to our new national beach. When the High Court's decision was handed down some farmers and commentators and politicians expostulated vigorously. Some like Joh Bjelke-Petersen ${ }^{16}$ were everywhere trying to enforce the notion that the Crown had had exclusive possession forever. Eventually the cockies ${ }^{17}$ settled down, even after the Wik flare-up ${ }^{18}$ and Tim Fischer's ${ }^{19}$ calls for 'bucketloads of extinguishment',

13 Ibid.

14 Ibid.

15 Ibid.

16 Premier of Queensland from 1968 to 1987.

${ }^{17}$ Colloquial Australian for 'farmers'.

18 Wik Peoples v Queensland ('Pastoral Leases case') [1996] HCA 40; [1996] 187 CLR 1; [1996] 141 ALR 129; [1996] 71 ALJR 173 (23 December 1996).

${ }^{19}$ Former Australian politician. Served as Deputy Prime Minister in the Howard Government from 1996 to 1999. 
and Australia gained an almost working set of native title registration arrangements. However, such negotiations generally take place far removed from the more densely settled areas.

Most Australians rarely have to consider the Indigenous provenance of the property they purchase because Native Title rights have often been long extinguished. To whom the land belonged before the Crown claimed it, is rarely a question that troubles most conveyancers. However, in at least Queensland, this historical anomaly could be remedied by a simple tweak in the Titles Office. Certificates of Title could easily contain a record of the First Nation that once lived, cared for and owned the land where anyone's residential block is now located. This could be done without stimulating any Native Title claims or challenging contemporary settled law.

Most of our symbols sit outside the Constitution and land is definitely the largest one. Australia's founding document contemplated a shifting definition of borders. New Zealand even has a mention ${ }^{20}$ in the document's introduction. With such a fluid definition of this Nation in our birth certificate surely Australians would feel they belong even more if they could look at a certificate of title that stretched back 3,000 generations or so.

This enhanced sense of belonging could also be used to generally improve Australians' sense of stewardship of this land. Section 51 of the Constitution contains a long list of the responsibilities of the Commonwealth Government but caring for country is not one of them. However, First Nations have continued to bear this sense of duty irrespective of the white shenanigans that have taken place in this great southern kingdom with no king.

All decent Australians should be encouraged to take on the responsibility of 'caring for country'. A whole of country problem needs a whole of country solution. Making 'caring for country' a federal responsibility, following the example long set by First Nations, would go some way to addressing the shambolic state of Australia's fragmented environment laws.

The federal government has previously embarked on a caring for country approach, albeit on a small scale. The Caring for Our Country initiative was established in July 2008 by the Rudd government. Its aim was to achieve a healthier, more resilient, better-protected environment that could continue to provide essential ecosystem services as climate change progressed. The initiative saw the integration of a range of national natural resource management programmes, as well as increased funding for Indigenous-specific Working on Country and Indigenous Protected Area programmes.

20 Aotearoa/New Zealand was originally incorporated into the Constitution as an Australian state. 
The programme was a success, securing better outcomes for Australia's environment. The initiative saw the uptake of more sustainable farming practices across Australia, improved water quality in the Great Barrier Reef, a two-million hectare increase in the amount of native vegetation with protected status, and carbon emissions reduced through the expansion of traditional fire management regimes across northern Savannas. In addition to these environmental benefits, the initiative also had many benefits for Indigenous people, who were empowered through this programme to, once again, take an even more active role in the management of their country.

Sadly, despite its success, the Caring for Our Country programme was not continued when the Abbott Federal Government took office in 2013.

The current de-centralised nature of Australia's environmental laws has created a situation where states and territories are auctioning off environmental protections in order to compete for corporate investment.

Waste management is a good example of how destructive a fractured policy approach can be. The former Queensland Liberal National Party Government loosened red tape around waste disposal in that state. When the $\$ 35$ per tonne waste levy was scrapped in Queensland in 2012, truck after truck then made their way to the Queensland border towns to dump their waste for free. In the 2016-17 financial year, a horrifying 900,000 tonnes of Sydney garbage was trucked over the Tweed River to Queensland. Other unscrupulous operators bought up industrial sites for the purpose of filling them with millions of discarded tyres.

Regulation around household garbage collection is treated in a similar ad hoc fashion across the states and territories. The amount of household waste that is diverted from landfill varies significantly. South Australia does it well, with over 75 per cent of its household waste diverted from landfill. However, Tasmania and Queensland are far behind with around 50 per cent diverted from landfill and the Northern Territory only recovers around 28 per cent. However, as a nation, Australia is well behind other countries in our waste recovery. Austria produces a similar amount of waste to Australia but diverts around 94 per cent from landfill. Without consistency across the states and territories it is almost impossible to have consistent best practice for waste disposal.

Likewise, our states and territories are primarily responsible for regulating rehabilitation requirements for mining and resource projects. States competing for mining dollars can choose to make their state more attractive for investment by reducing the rehabilitation requirements after the closure of their mines. Whilst the state may benefit from such a short-term investment boost, our nation's environment is the long-term loser. A national co-ordinated approach to caring for the environment, or 'caring for country' as do First Nations, would prevent such a race to the bottom of the environmental scrap-heap by the states. Strong national 
leadership could see uniform waste management where the goal is for best practice, not more ephemeral dollars. It could ensure corporate responsibility is not used as a bargaining chip for investment dollars. This nation's corporations would have a greater responsibility to care for their precious environment.

If the list of federal responsibilities included what the First Nations considered to be their responsibility for over 60,000 years, 'caring for country', there would be a longer term focus on decisions made about our natural landscapes. It would go some way to removing short-term politics from development decisions and ensure that the national interest is considered. Suddenly issues such as the degradation of good productive farming land, urban development, falling biodiversity, water security, and the threat of climate change would have to be factors considered by all levels of government. Australia's three different tiers of government would be more likely to work together to solve these common problems. And the Commonwealth would have some stick to use alongside the tax-dollar carrots. The environment belongs to all Australians, not just farmers and Traditional Owners - every single one of us. It sustains and nurtures us all.

In Senator Dodson's Yawuru country, native title holders are working towards a sense of mabu liyan, a healthy spirit, in mabu buru a good place. Signs at Broome airport welcome tourists in those terms. This sense of connection could be energized for all Australians in all parts of the country, from the beach to the bush, from the desert to the Daintree rainforest.

And just as places can be recognised and acknowledged, so too can our founding documents. Isn't it time this nation's birth certificate recognised all its parents? Isn't it time, like Vincent Lingiari ${ }^{21}$ fifty years before, that we pour our own sand through our own hands and walk like mates together into the future, having recognised and celebrated the reality of our past.

21 Aboriginal rights activist and member of the Gurindji people. At an important event in Australian history, the then Prime Minister, Gough Whitlam, poured the local sand into Vincent Lingiari's hands, symbolically handing the Wave Hill station back to the Gurindji people. 